\title{
Process Model of Quality Cost Monitoring for Small and Medium Wood- Processing Enterprises
}

\section{Model procesa praćenja troškova kvalitete za mala i srednja drvoprerađivačka poduzeća}

\author{
Preliminary paper • Prethodno priopćenje \\ Received-prispjelo: 7. 11. 2014. \\ Accepted-prihvaćeno: 6. 11. 2015. \\ UDK: $630 * 79 ; 658.5$ \\ doi:10.5552/drind.2015.1437
}

\begin{abstract}
Quality is not only a technical category and the system of quality management is not only focused on product quality. Quality and costs are closely interlinked. The paper deals with the quality cost monitoring in small and medium wood-processing enterprises (SMES) in Slovakia, and also presents the results of the questionnaire survey. An empirical study is aimed to determine the level of understanding and level of implementation of quality cost monitoring in wood-processing SMEs in Slovakia. The research is based on PAF model. A suitable model for quality cost monitoring is also proposed in the paper based on the research results with guidelines for using the methods of Activity Basic Costing. The empirical study is focused on SMEs, which make $99.8 \%$ of all companies in the branch, and where the quality cost monitoring often works as a latent management subsystem. SMEs managers use indicators for monitoring the processe performance and production quality, but they usually do not develop a separate framework for measuring and evaluating quality costs.
\end{abstract}

Key words: quality, quality costs, small and medium wood-processing enterprises, process

SAŽETAK • Kvaliteta nije samo tehnička kategorija i sustav upravljanja kvalitetom nije fokusiran samo na kvalitetu proizvoda. Kvaliteta i troškovi međusobno su usko povezani. Ovaj se članak bavi praćenjem troškova kvalitete proizvodnje u malim i srednjim drvoprerađivačkim poduzećima u Slovačkoj. U njemu se ujedno prezentiraju rezultati provođenja istraživanja anketnim upitnikom. Iskustvene se studije temelje na određivanju razine razumijevanja i razine uvođenja praćenja troškova kvalitete u proizvodnji u malim i srednjim drvoprerađivačkim poduzećima u Slovačkoj. Istraživanje je utemeljeno na PAF modelu. U radu se predlaže najprihvatljiviji model praćenja troškova kvalitete s obzirom na dobivene rezultate istraživanja i daju se naputci za primjenu metoda Activity Basic Costing. Istraživanje se temelji na malim i srednjim poduzećima, koja čine 99,8\% svih poduzeća u drvoprerađivačkoj djelatnosti i u kojima se praćenje troškova kvalitete provodi u sklopu podsustava upravljanja. Menadžmenti u malim $i$ srednjim poduzećima najčešće se koriste različitim indikatorima za praćenje proizvodnog sustava i kvalitete proizvodnje, no najčešće ne razvijaju zasebne odrednice za mjerenje $i$ vrednovanje troškova kvalitete.

Ključne riječi: kvaliteta, troškovi kvalitete, mala i srednja drvoprerađivačka poduzeća, proces

\footnotetext{
${ }^{1}$ Author is professor at University of Zagreb, Faculty of Forestry, Zagreb, Croatia. ${ }^{2}$ Author is professor at College of Banking, Banská Bystrica, Slovakia. ${ }^{3}$ Author is assistant at Faculty of Wood Science and Technology, Technical University in Zvolen, Slovakia. ${ }^{4}$ Author is professor at Catholic University in Poprad, Department for Management, Poprad, Slovakia. ${ }^{5}$ Author is doctor of science at University Matej Bel, Faculty of Economics in Banska Bystrica, Slovakia.

${ }^{1}$ Autor je profesor Sveučilišta u Zagrebu, Šumarski fakultet, Zagreb, Hrvatska. ${ }^{2}$ Autorica je profesorica Visoke škole za bankarstvo, Banska Bistrica, Slovačka. ${ }^{3}$ Autorica je asistentica Tehničkog sveučilišta u Zvolenu, Fakultet drvne tehnologije i znanosti, Slovačka. ${ }^{4}$ Autor je profesor Katoličkog sveučilišta u Popradu, Zavod za menadžment, Poprad, Slovačka. ${ }^{5}$ Autorica je doktorica znanosti Sveučilišta Matej Bel u Banskoj Bistrici, Ekonomski fakultet, Slovačka.
} 


\section{INTRODUCTION}

\section{UVOD}

The quality costs are very closely linked to a company's productivity and its performance (Bekhta et al., 2012). Al-Dujaili (2013) presents a research aimed at discovering a relationship between the quality improvements, quality costs, and productivity. By defying the concept of quality control, referring to the types of quality costs - prevention costs, appraisal costs, internal and external failure costs; and seeking to measure the impact of the quality improvement on productivity and costs, creates an opportunity for the company to improve. J. M. Juran (1987) was one of the first authors to write about quality costs. He describes the Quality Cost Optimum Model, which is a baseline for other models. Same quality costs categories were classified in the study of Su et al., (2009) in terms of trade-off relationship (increase of control costs resulting in the decrease of failure costs and vice versa). Integrated time delays in the statistical analysis were used to compute a balanced point of quality costs, which can provide a useful guidance on quality cost savings. Srivastava (2008) used these categories through the DMAIC (DefineMeasure-Analyse-Improve-Check) methodology for quality cost analysis, to identify significant quality cost drivers and then to suggest measurements and directions for the next research. Branca and Catalão-Lopes (2011) contributed to the academic research through updating the traditional prevention-appraisal-failure approach by the strategic reaction of other companies, which affects market shares and profits.

The economic effects of quality improvement were reviewed by Eben-Chaime (2013), who demonstrated that the decrease of production costs in order to achieve a lower quality level is not an economic advantage (Freiesleben, 2005; Stasiak-Betlejewska, 2012), but vice versa - production costs could increase extremely due to low quality level. Kajdan (2007) combined the stream performance indicators with quality indicators to optimize the process on the bases of cost minimization. Trade-off relationship between the quality costs was defined in the study by Lin et al., (2012) related to a new product development, showing the impact of innovation speed on a project's success is mediated by development cost and product quality (Novakova and Kusy, 2010; Novakova, 2003). Traditionally, design quality and conformance quality are considered separately in the literature. In the paper by $\mathrm{Wu}$ (2010), both quality dimensions were integrated into stylized quality decision models for synthesizing quality cost design, conformance to quality cost, and product revenue components. Chiadamrong (2003) presented in his paper an empirical model of quality as a function of traditional cost model (prevention-appraisal-failure expenses) and hidden-opportunities in quality loss costs. This approach provides a view on tracking costs not only associated with production, but additionally with costs associated with quality. A study performed by Lari and Asllani (2013) shows the relationship of quality costs and operational processes and introduces a management support system in order to help the companies to continuously measure, check, and minimize quality costs. Fassoula (2005) addresses processes with a direct or indirect impact on quality costs, with the of implementing the process oriented diagnostic tool followed by assessment procedures for goal setting and action planning.

The main aim of the paper is to present the idea of quality cost monitoring as a framework design based on particular manufacturing conditions of small and medium enterprises in Slovakia. The research was carried out with a selected sample of small and medium manufacturing enterprises focusing on the current state of awareness and potential of quality cost control. The aim of the activity was to answer the basic question: „To what extent and on what level is monitoring of quality costs used in manufacturing in small and medium enterprises in Slovakia?"

\section{MATERIAL AND METHODOLOGY} 2. MATERIJAL I METODE

Small and medium wood-processing enterprises were the target and objective of the research. There are approximately 23 million SMEs in the European Union that offer approx. 75 million work places that represent $99.8 \%$ of all enterprises. Within Slovakia, SMEs represent about $99.1 \%$ of all registered enterprises. SMEs show flexibility in using progressive technologies and are a driving force for the economy development in creating job opportunities and are the main initiators of the growth of living standards within each country. According to the recent data of the Agency for Small and Medium Enterprise Development, in 2011 there were 153,283 small and medium enterprises (excluding sole traders) registered in Slovakia (Potkány, 2011).

For the purpose of collecting financial data for the research addressing the enterprises, a random sampling of 300 manufacturing wood-processing SMEs was selected from various areas of the national economy of the Slovak Republic. The empirical research was specifically targeted to finding the current level of use of tools for monitoring specific groups of quality costs, its evaluation, and organisational security from the viewpoint of a responsible controller by using process management. The basis for quality cost monitoring in wood-processing SMEs can be found in the implementation of the models and conditions that were created previously. This model should help enterprises create a compact reporting system for monitoring the quality costs and their evaluation.

The research methodology consists of four phases. In the first phase, methods of summary, synthesis, and analogy of the knowledge were used and a short review was prepared. In the second phase, a questionnaire was used to perform an empirical study, which represents the analysis of the situation of the solved practical issues within wood-processing SMEs in Slovakia. When working on the basic part of the questionnaire, the model of quality cost monitoring was based 
on PAF principles (prevention, appraisal, costs of failure). This questionnaire was evaluated according to graphic and description methods. In the third phase, a model of quality cost monitoring for small and medium manufacturing enterprises was designed.

The aim of the empirical research was to discover the level of understanding and the level of implementing the quality cost control in Slovak small and medium manufacturing enterprises, as well as to identify the potential possibilities and interest of implementing this system into an enterprise practice in future. Partial aims of the research were to find out if an enterprise practice in the given area corresponds with modern knowledge of theory, to process data gathered and consequently to formulate the findings and recommendations, which would enrich theory and contribute to a higher quality practice in an enterprise. The basic set of research was represented by small and medium-sized businesses located in Slovakia. According to the Statistical Office of the Slovak Republic, 153,284 small and medium sized enterprises were registered in 2011. Due to the large size of the basic set, it was not possible to include all small and medium enterprises into this research and therefore sampling was made through survey data. To choose the units from the basic set of the sample, one must make a deliberate choice based on the criteria defined by the directive EK No 2003/361/EC. The intended scope of the sample covered 300 enterprises. Determination of the scope of the sample set was the result of the following relation (Scheer, 2007):

$$
n=\frac{z_{\alpha / 2}^{2} \cdot p \cdot(1-p)}{\Delta_{p^{2}}}
$$

where $n$ is scope of sample set, $z_{\alpha} / 2$ are values of standard random quantity at $95 \%$ reliability, (i.e. the value $\alpha=0.05$ corresponds to $\mathrm{z}=1.96), \Delta p$ requires exactness, resp. an error of estimation (determined at $5.65 \%$ ) and $p$ is ratio (relative frequency) quality sign in the basic set (determined at $50 \%$ ). The actual scope of the sample set was at the level of 186 businesses due to the fact that $62 \%$ of the questionnaires were returned. Despite the reduced scope of the sample set, the actual scope of the sample set may be considered as representative. Due to the facts presented by Kozelová et al. (2014), it can be stated that with respect to the research of institutions at the national level, the minimum scope of the sample set should be equal to 150 companies. The reduced number of sample set influenced the error of estimation, which rose to $7.18 \%$.

The ratio of questionnaire return was $62 \%$, which meant 186 completed questionnaires. When de- signing the methodology for evaluating the questionnaire, it was important to take into account that the selected surveyed enterprises stood for a relatively small sample to apply statistical methods of the questionnaire survey evaluation. The questionnaire survey was evaluated by a description method, numerically and in percents in tables and graphs. Within the questionnaire evaluation, the correlations between the quality cost control and quality management were established and so the questions were evaluated either individually or in groups of narrowly coherent/related questions. Using the statistical testing method, the level of representation of the sample file of companies was confirmed by the application of Pearson's chi-squared test $\left(\chi^{2}-\right.$ test), which is also known as the 'goodness-of-fit' test. The calculation of the level of representation was done at the level of a statistical significance $\alpha=0.05$. The expected values of theoretical distribution were provided from the Statistical Office of the Slovak Republic. The frequencies observed, and the expected (theoretical) frequencies are shown in Table 1. The degree of freedom $(k-1)$ is equal to two, since three categories of business organisation were defined.

The achieved $\chi^{2}$ value was higher than the critical $\chi^{2}$ value at the level of statistical significance of $\alpha=$ 0.05 for 2 degrees of freedom (3 - 1), which in particular presents the value of 5.991 (value in statistical tables). Since 40.59>5.991, the null hypothesis cannot be accepted and cannot be stated that the sample file of companies represents their theoretical distribution. Although according to the statistical yearbooks, the ratio of small enterprises in Slovakia is bigger than the ratio of medium size enterprises, in our research there was a dominance of middle size enterprises. It is a given fact that the scope of the research was to find out the level of implementation of quality cost control in enterprises by following the indicators of quality costs. Based on logical judgement, these levels will be higher in the case of medium size enterprises and that is why this research is focused on this area.

Based on the conducted research, $74 \%$ of the questioned enterprises do not consider management of quality and quality cost control as identical areas, while $48 \%$ of those asked think that these two areas still have something in common. These two answers can be considered as correct, which means that most of the respondents have the proper knowledge of the subject matter (Figure 1).

Figure 2 represents the percentage of the answers of enterprises to question Q2 - Do you deal with monitoring individual groups of costs in terms of PAF model methodology? and question Q3 - Do you have your

Table $1 \chi^{2}$-test by enterprise size

Tablica 1. $\chi^{2}$-test vezan za veličinu poduzeća

\begin{tabular}{|l|c|c|c|c|}
\hline & $\boldsymbol{n p}_{\mathbf{i}} \mathbf{( \% )}$ & $\boldsymbol{n}_{\mathbf{i}}(\mathbf{\%})$ & $\left(\boldsymbol{n}_{\mathbf{i}}-\boldsymbol{n}_{\mathbf{i}}\right)^{\mathbf{2}}$ & $\boldsymbol{\chi}^{\mathbf{2}}$ \\
\hline Micro enterprises / Mikro tvrtke & 10 & 9.56 & 0.19 & 0.02 \\
\hline Small enterprises / Male tvrtke & 50 & 29.41 & 423.95 & 8.48 \\
\hline Medium enterprises / Srednje velike tvrtke & 30 & 61.03 & 962.86 & 32.09 \\
\hline$\Sigma$ & & & & 40.59 \\
\hline
\end{tabular}



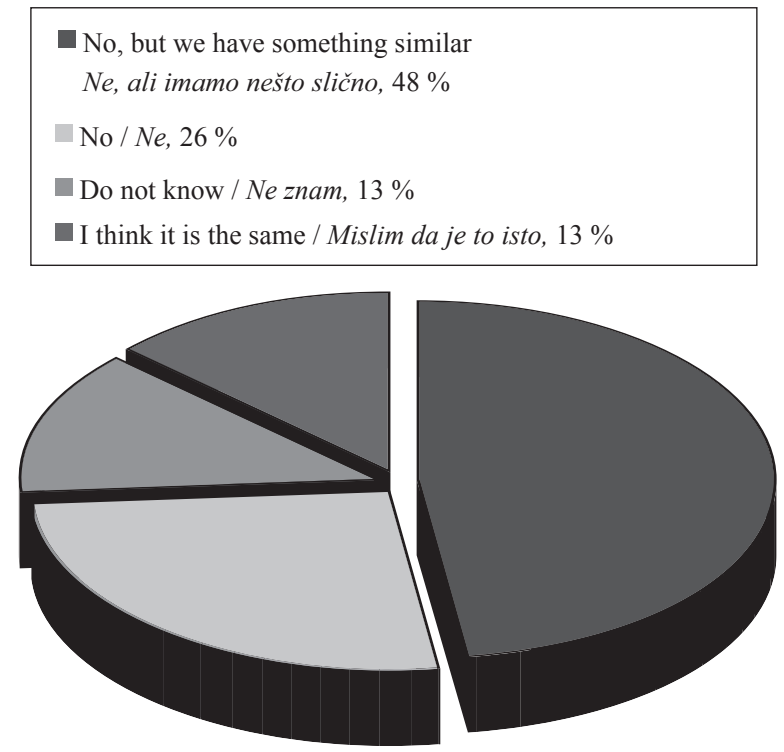

Figure 1 Question 1 - Do you think that quality cost control is the same as the quality management?

Slika 1. Analiza odgovora na pitanje 1.: Mislite li da je kontrola troškova kvalitete isto što i upravljanje kvalitetom? own methodology for determining costs for quality appraisal?

The present results show that, from the viewpoint of monitoring of individual groups of costs according to the PAF model, enterprises pay bigger attention to monitoring cost entries for external failures (67\%). Our own methodology for cost monitoring has only a small group of respondents $(26 \%)$ and it only concerns scoring reclamations/claims. Figure 3 presents the answer structure of the enterprises that, within question Q2, presented a positive viewpoint of monitoring any group of quality costs according to PAF model. It can be stated that companies mostly deal with costs of external and internal failures - the losses caused by poor quality (in total $65 \%$ of answers).

Question Q4 deals with personnel representation from the viewpoint of a quality controller. Figure 4 presents the results among the surveyed enterprises that deal with quality cost control; these have mostly multifunctional jobs ( $74 \%$ of respondents) and these represent posts of quality managers, agents for quality and manufacturing managers. Therefore, only $4 \%$ of the surveyed enterprises have a job position of quality controller.

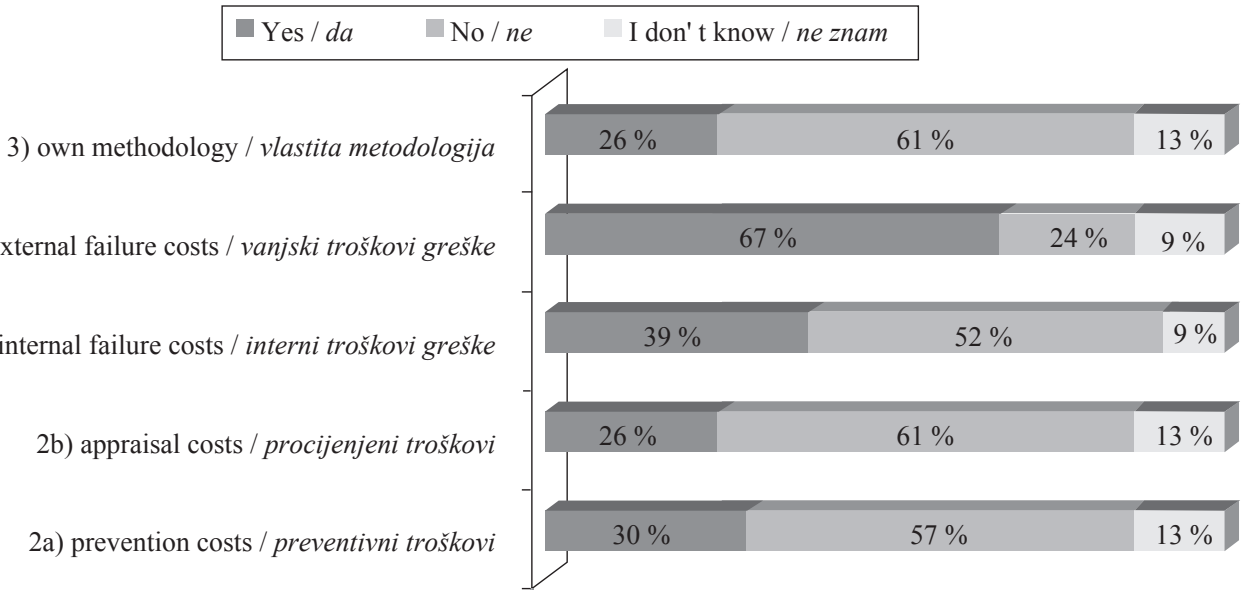

Figure 2 Questions Q2 and Q3

Slika 2. Analiza odgovora na pitanja Q2 (Pratite li pojedine skupine troškova kvalitete prema PAF modelu?) i Q3 (Imate li vlastitu metodologiju za praćenje troškova loše kvalitete?)

2d) external failure costs / vanjski troškovi greške

2c) internal failure costs / interni troškovi greške

b) appraisal costs / procijenjeni troškovi

2a) prevention costs / preventni troškovi

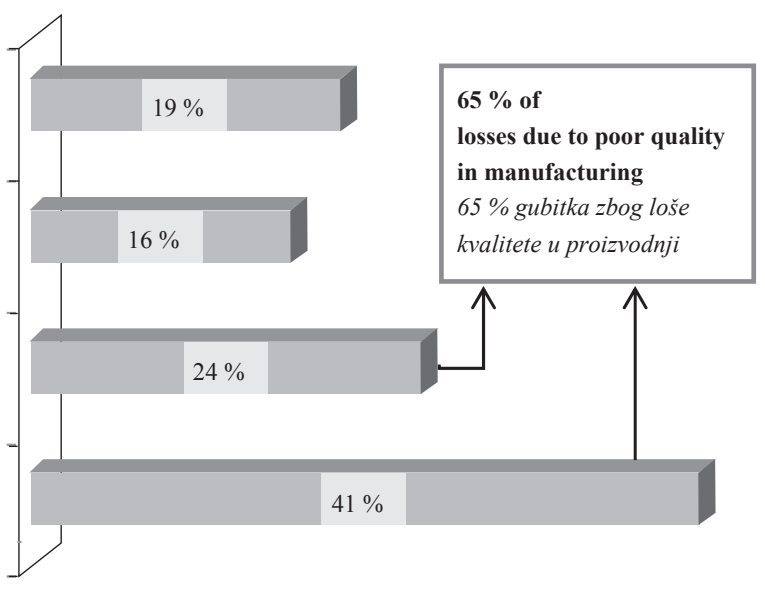

Figure 3 Percentage of individual groups of quality costs

Slika 3. Postotni udio pojedinih promatranih skupina troškova kvalitete 


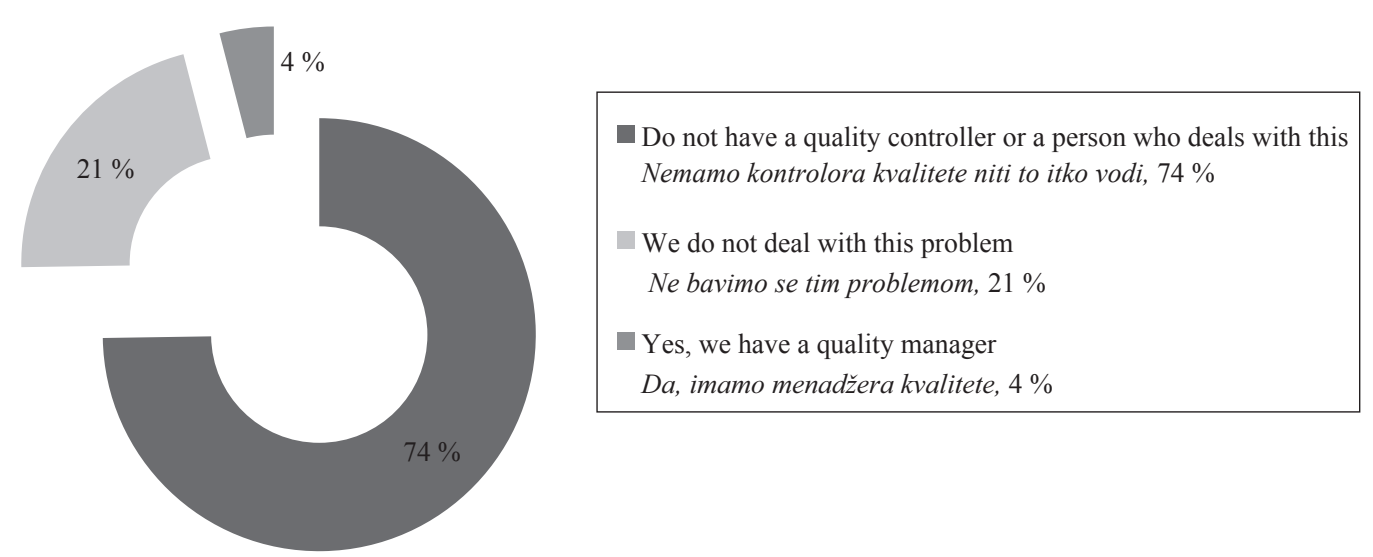

Figure 4 Question 4

Slika 4. Analiza odgovora na pitanje Q4 (Imate li uposlenika koji je zadužen za kontrolu kvalitete u poduzeću?)

ISO standards are mostly focused on the economic aspect of quality; there is a presumption that enterprises, which have implemented the quality management system according to ISO standards and at the same time also the process map, could also deal in more detail with the economics of quality. These results are presented in Figure 5.

Figure 5 results in the following:

- The majority of respondents are certified or are in the certification process according to ISO standards $(57 \%)$ and another $37 \%$ are interested in certification in future;

- $\quad$ Also the majority of respondents have set up a process map or will prepare it in a near future (57 $\%$ in total);

- $\quad$ Referring to presented data, $65 \%$ of respondents deal with losses due to faulty manufacturing.

In the case of the question that focused on the potential of using quality cost control, it can be stated that $29 \%$ of respondents are interested in implementing quality cost control system into their enterprises,
$34 \%$ stated that ,yes, but we are not sure“, and the rest, $37 \%$ did not show interest in implementing quality cost control within the enterprise at all.

The summary of the presented findings can be formulated as the results of the conducted survey: Slovak small and medium manufacturing enterprises mostly deal with costs of quality, more precisely with costs for external and internal failures (losses caused by poor quality), which means that from the viewpoint of the level of development of quality cost control, these enterprises are just in their initial phase of such development.

\section{RESULTS AND DISCUSSION 3. REZULTATI I RASPRAVA}

The findings of the empirical research show that wood-processing small and medium enterprises in Slovakia do not actually use a single monitoring methodology and appraisal of quality costs, and in general they do not use further possibilities that can be applied in the

8) I do not know what it means / Ne znam što je to

7) No, we do not have process mapping $\mathrm{Ne}$, nemamo mapiranje procesa

6) We will prepare it in the near future Pripremamo mapiranje u budućnosti 5) Yes, we have process mapping Da, imamo mapiranje procesa

4) No, we do not have ISO standards Ne, nemamo ISO standard

3) No, but we would be interested in future Ne, ali želimo to u budućnosti

2) We are in the certification process at present U procesu certifikacije smo

1) Yes, we have ISO standards / Da, imamo ISO standard

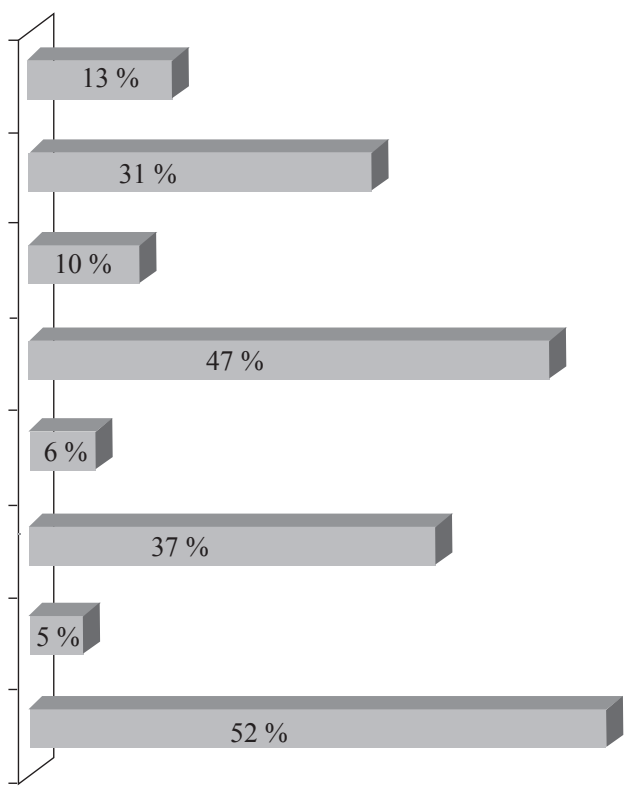

Figure 5 Questions Q5 and Q6

Slika 5. Analiza odgovora na pitanje Q5 (Imate li certifikat prema ISO standardima?) i pitanje Q6 (Obavljate li mapiranje procesa?) 
present area. The present process model of quality cost for wood-processing SMEs (steps 1-9 and Figure 7) consists of components that take into consideration the aspects of both process quality and bookkeeping.

1a) Aspect of quality and processes - identification of enterprise quality objectives

To develop a target model of total costs of quality for wood-processing SMEs, the first step is to set objectives in the area of quality that an enterprise wants to reach. These objectives must be a part of strategic aims and future direction of an enterprise. For this purpose, the majority of objectives should be measurable values within the enterprise, as this is a basic feature of the quality cost monitoring.

2a) Aspect of quality and processes - identification of enterprise processes

One of the basic objectives of quality is to identify all company processes listed in an enterprise processes map. For the purpose of monitoring the costs of quality, it is necessary to identify its individual parts of the processes and indicators of their quality measurement.

3a) Aspect of quality and processes - classification of costs for quality

On the bases of the stated measurable quality objectives, identification of enterprise processes, activities and indicators of their quality measurement is another step in the classification of quality costs (model PAF) in individual processes, which will be suitable and possible from the viewpoint of information accessibility in the enterprise in question. Identification of the above listed indicators enables to consider the aspect of quality and processes in the model to be developed.

1b) Aspect of book-keeping - analysis of the nominal ledger, and account content, analysis of departments

For the complex understanding of monitoring the costs of quality, it is necessary to interconnect both areas (book-keeping and quality) and redefine the basic input economic information. This means re-evaluation of content of individual analytic accounts of the nominal ledger, their targeted selection and analysis of departments in relation to quality costs. Data from the nominal ledger will, via the accounting crosswalk, enter the management profit and loss account, which will be in vertical division starting from the structure of $\mathrm{ABC}$ calculation.

2b) Aspect of book-keeping - division of costs through Activity Basic Costing

Since management profit and loss account comes from the methodology of the process calculation $\mathrm{ABC}$, the enterprise costs have to be divided into activities.

3b) Aspect of book-keeping - definition of transfer crosswalk and management profit and loss account

Defining the suitable transfer crosswalk between analytic accounts of nominal ledger and management profit and loss account is considered to be an important and essential part of the given model. The essentials of transfer crosswalk are illustrated in Figure 1 in relation to the definition of work flow. The management of profit and loss account will be the basis for monthly appraisal of enterprise results. We propose the processing of management profit and loss account in gradual classification from the gross revenues via gradual adjustments of individual costs/revenues to overall management result before taxation (EBT). In the following components (step 4-9) there is cross connection of the point of quality and book-keeping.

4) Identification of cost of quality according to analytical accounts and information sources

In order to identify quality costs, it is necessary to determine the information sources that can be used in the enterprise, and also to define particular analytical accounts and corresponding account documents. In case some account documents are not sufficient, considering data from other enterprise record-keeping (reports, statistical indicators, trend analysis) is also recommended.

5) Collection of data about costs of quality i.e. definition of ,workflow ${ }^{66}$

This step is considered to be the most important when designing the model, since it is necessary to set which approach will be the most effective for data collection. Therefore, it is necessary to re-evaluate the content of each chosen item of quality costs from the point of view of secondary division (material, wages, energy, services, etc.) and to find the way how a controller can obtain these data i.e. how, who from, where and when. In this phase, it is also necessary to define a codebook of individual costs of quality. Information about costs of quality can be obtained from bookkeeping and directly from delivered invoices with the identification of the department of the costs of quality (cost of quality $=\mathrm{CQ}$ ) according to PAF model or the complex enterprise information system.

6) Software support in creating a manager report

Thus obtained information is further evaluated via extension of enterprise information system, which is represented by information system or a dynamic model in the MS Excel environment in the proposed model. This extension of enterprise information system is essential for the formation and use of information database of our designed model in form of a reporting message. In the proposed process model of costs, quality costs will be monitored not only as absolute indices but also as ratio NQ indices, ratio indices to revenues or to overall costs. At the same time, it will be possible to monitor deviations from minimally acceptable phases, and their cumulative sum within the accounting phase also in interim comparison.

7) Suggestion for reporting and communication with users

This phase deals with design of management profit and loss account in its horizontal division to yearly budget plan, flexible budget (FB - calculation of planned prices and costs for the real capacity of sales), reality, variances, estimates and proposal for correction measures for future. In vertical division, the manager report should be structured from the point of the view of the $\mathrm{ABC}$ calculation, meaning that costs should be 
...... Jelačić, Šatanová, Sedliačiková, Závadský, Závadská: Process Model of Quality Cost...

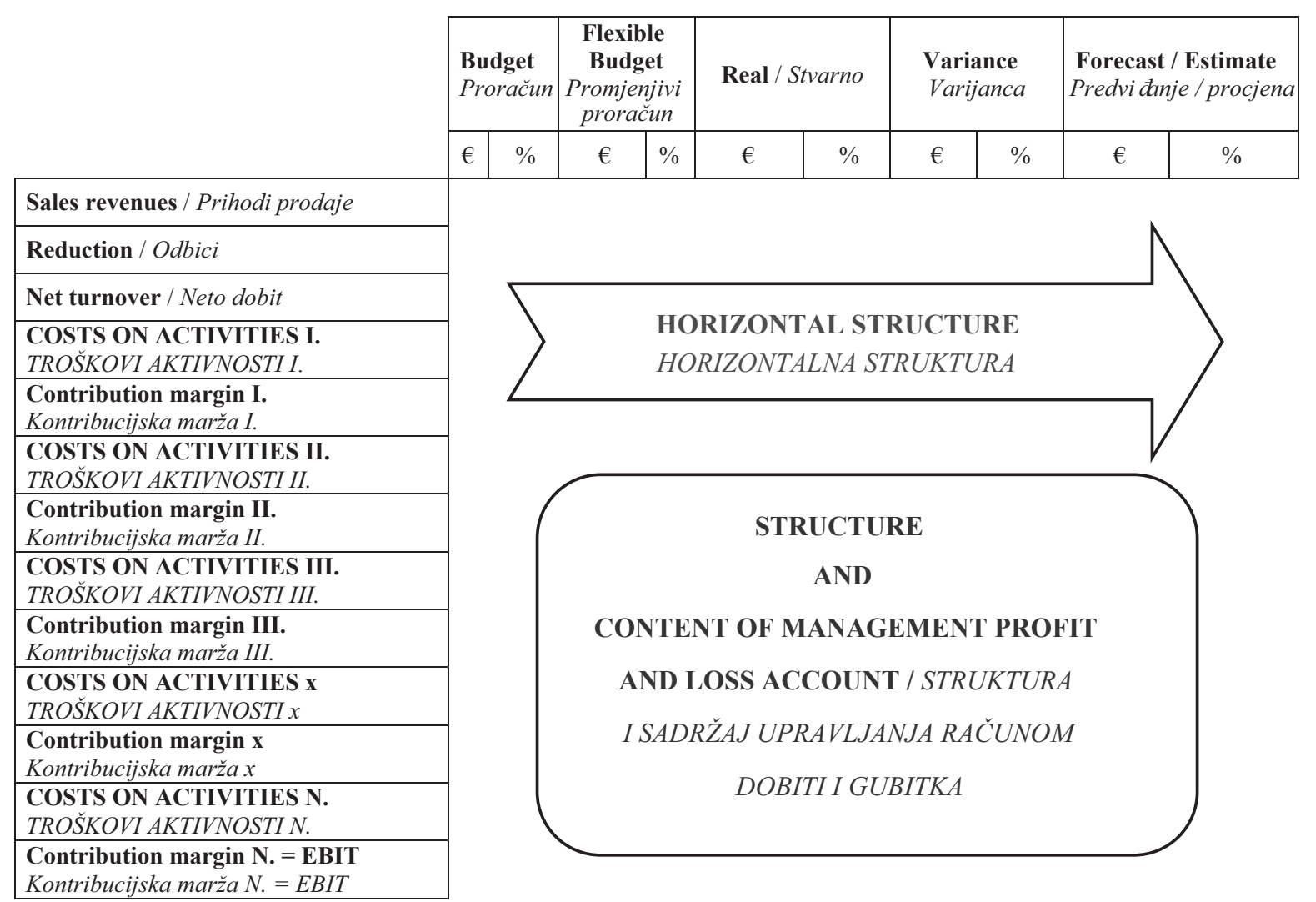

Figure 6 Proposed management profit and loss account based on $\mathrm{ABC}$ calculation Slika 6. Prijedlog za upravljanje računom dobiti i gubitka utemeljen na ABC metodi

allocated on activities. Figure 6 presents the proposed management profit and loss account in its vertical and horizontal division.

8) Analysis, management variance and effects of quality cost monitoring

For the analysis of costs of quality, quality indicators should be amended so as to show the effects of monitoring the costs of quality and these should persuade enterprise managers to focus on the designed subject matter. The detection of savings in costs of quality (in the area of internal errors - non-productive costs of material, energy, work, in the area of external failures - elimination/minimising of claims and other related costs - e.g. costs of transportation and such like) can be an important effect of the quality cost monitoring. External effects of monitoring the costs of quality will also become evident in terms of customers satisfaction and loyalty, in positive references and spreading of enterprise good reputation, which can strengthen its competitiveness in the market.

9) Communication with TOP management in form of monthly manager reports

Detected variances from the planned conditions (positive, negative) are necessary to be discussed on the level of TOP management in form of monthly manager reports and remedial measures should be prepared to eliminate negative variances and to establish how to use the effects of the positive ones.

The proposed process model of quality cost monitoring for wood-processing SMEs interconnects the aspect of processes and the aspect of book-keeping (identification of individual analytic accounts). The proposed model can also partly use the ABC costing methodology, via which it is possible to assign costs of quality (sources) through activities (processes) towards individual cost objects (orders, cost pool, processes) (Vetráková et al., 2013). This approach, however, requires the use of $\mathrm{ABC}$ costing methodology in enterprise management i.e. in designing calculations and division in enterprise management i.e. in creating calculations and division of overall costs for orders as well as in approving the present state of mind and planning orders. The following figure presents a transparent process model of the quality cost monitoring, which is generally suitable for small and medium manufacturing enterprises from the point of view of versatility of its use.

\section{CONCLUSION}

\section{ZAKLJUČAK}

Slovakian small and medium wood-processing companies make $99.8 \%$ of all companies in the branch. As shown in the research, these companies use the methodology for monitoring quality costs that is not sufficient and they do not define their internal guidelines. In this research, the model for monitoring these costs is recommended. Big companies have the methodology for monitoring quality costs, which is also used in their daughter companies. To make small and 
Process model of quality cost monitoring in woodprocessing SMEs / Model procesa praćenja troškova kvalitete u drvoprerađivačkim SME-ima

a) Aspect of quality and processes / $\mathrm{Sa}$ stajališta kvalitete i procesa

1a) Identification of quality objectives and definition of indicators / Identifikacija ciljeva kvalitete i indikatora

2a) Identification of process activities and quality measurement indicators Identifikacija aktivnosti i indikatora mjerenja kvalitete

3a) Classification of quality costs considering all available information sources / Klasifikacija troškova kvalitete prema svim dostupnim informacijama b) Aspect of book-keeping / Sa stajališta knjigovodstva

1b) Analysis of nominal ledger and content of accounts, analysis of departments / Analiza glavne knjige $i$ računa te odjela

2b) Cost allocation on activities Dodjeljivanje troškova prema aktivnostima

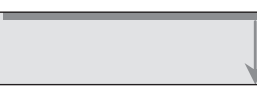

3b) Definition of transfer crosswalk and management profit and loss account Definicija transfera i računa dobiti i gubitka

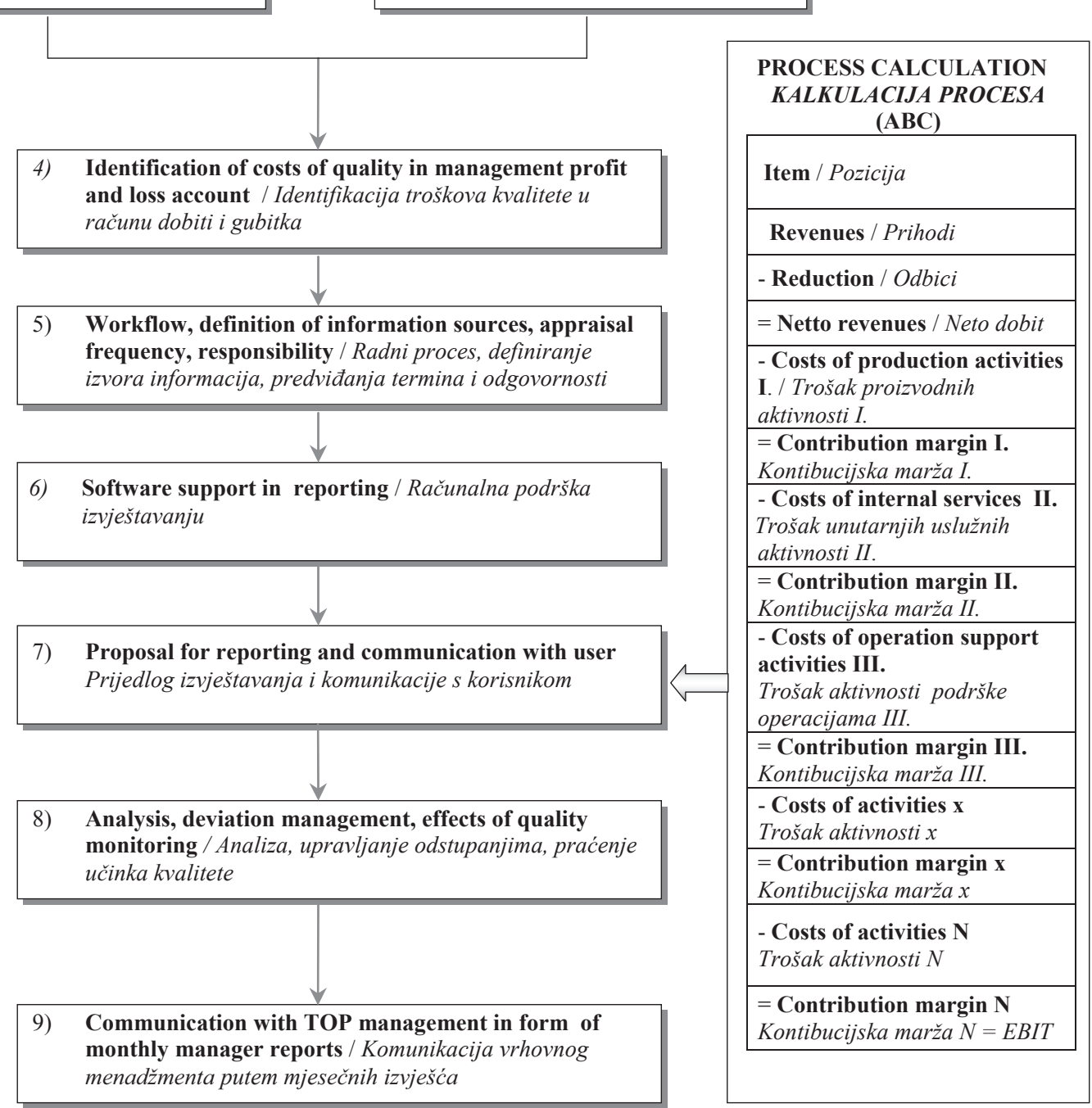

Figure 7 Process model of quality cost monitoring in wood-processing SMEs

Slika 7. Model procesa praćenja troškova kvalitete proizvodnje u malim i srednjim drvoprerađivačkim poduzećima 
medium companies able to use the methods of Activity Basic Costing, it is necessary to do as follows:

1. According to standard ISO 9001/2008. Quality management system. Requirements, companies have to create a process map, which is the basis for company process management;

2. Processes have to be divided to management, main and additional (and based on this division activities have to be defined);

3. For particular activities, the size should be defined (Activity Cost Drivers);

4. For particular process, it is necessary to establish measurement criteria NQ, i.e. particular costs divided to fix and variable in groups NP, NH, NI and NE;

5. At this point, it is necessary to create horizontal and vertical structure of reporting.

The aim of each enterprise should be to eliminate the losses, detect weaknesses, and provide preventive measures, i.e. create an effective feedback system, which would signal weaknesses on time and offer the responsible staff valuable information for solving the present problems. The above problems force companies to use modern management tools, one of which is controlling in the area of quality management. Its task is to secure the quality of management by equally relevant information concerning quality with the aim to fulfil the set objectives, detect weaknesses, and identify process defects.

This paper analyses the current state of the subject matter based on the reviewed literature with a focus on quality cost control. Via the questionnaire survey, the level of understanding, implementation, and establishment of quality cost monitoring was determined in Slovak wood-processing SMEs and the complex model for quality cost monitoring was proposed. The essence of the introduced model is to present the sequence of steps necessary for applying a quality control concept in wood-processing SMEs, which is based on the identification of quality aims, processes, costs of quality, collection of data, and definition of information sources aimed at developing the pattern of a manager report. Such reports have their own horizontal and vertical structure. The vertical structure of the manager report is created by individual items of managing the profit and loss account, beginning with revenues through gradual deduction of costs of quality until the economic profit before taxation (EBT). This structure is mainly used for identifying individual costs of quality groups and appraising them through simple relative ratio indicators. The horizontal structure of a manager report creates two basic parameters - time and variant, which create the basis for the so called management system through variances. Time is given by the period of monitoring (month, quarter, and year). This version is based on comparison of a yearly plan, flexible budget, and a real situation in the given month, with comparison of the estimate till the end of year (E - estimate) and plan (B - budget).The proposed model of quality cost monitoring can be helpful for enterprises to create a compact reporting system for monitoring costs of quality and their further evaluation on the basis of controlling principles, which will show the transparent flow of costs and detect hidden reserves and enable their elimination. As small and medium enterprises have proven highly adaptable to receive and use progressive tools in the area of management, it can be stated that our proposal could be used in manufacturing SMEs regardless of the branch of economics.

Controlling is an effective basis of active management of companies and it can be used in different functions such as financial controlling, investment controlling, cost controlling, personnel controlling, and finally also quality controlling. These particular controlling subsystems are not to be used partially, since they make a system with mutual interactions and they support and fulfil each other.

\section{Acknowledgement - Zahvala}

This paper was processed in the framework of projects No. 1/0581/12, No.1/0527/14 and No. $1 / 0268 / 13$ as the result of authors' research with significant help of VEGA agency, Slovakia.

\section{REFERENCES}

5. LITERATURA

1. Al-Dujaili, M. A. A., 2013: Study of the relation between types of the quality costs and its impact on productivity and costs: verification in manufacturing industries. Total Quality Management and Business Excellence, 24 (3-4): 397-419 http://dx.doi.org/10.1080/14783363.2012.669552.

2. Bekhta, P.; Niemz, P.; Sedliačik, J., 2012: Effect of prepressing of veneer on the glueability and properties of veneer-based products. European Journal of Wood and Wood Products, 70 (1-3): 99-106 http://dx.doi.org/10.1007/s00107-010-0486-y.

3. Branca, A. S.; Catalão-Lopes, M., 2011: Strategic interaction and quality choice. Total Quality Management and Business Excellence, 22 (3): 265-273 http://dx.doi.org/10.1080/14783363.2010.530809.

4. Chiadamrong, N., 2003: The development of an economic quality cost model. Total Quality Management and Business Excellence, 14 (9): 999-1014 http://dx.doi.org/10.1080/1478336032000090914.

5. Eben-Chaime, M. A., 2013: Note on: the economic effects of quality improvements. Total Quality Management and Business Excellence, 24(3-4): 374-377 http://dx.doi.org/10.1080/14783363.2012.734952.

6. Fassoula, E. D., 2005: Reverse logistics as a means of reducing the cost of quality. Total Quality Management and Business Excellence, 16 (5): 631-643 http://dx.doi.org/10.1080/14783360500077575.

7. Freiesleben, J., 2005: The economic effects of quality improvement. Total Quality Management and Business Excellence, 16 (7): 959-969 http://dx.doi.org/10.1080/14783360500077419.

8. Juran, J. M., 1987: Quality cost optimum model. Quality progress, 20 (4): 7-14.

9. Kajdan, V., 2007: Why Quality, Cost and Business Excellence are Inseparable. Total Quality Management and Business Excellence, 18 (1-2): 147-152 http://dx.doi.org/10.1080/14783360601052139.

10. Kozelová, D., et al. 2014: Analysis of consumer behavior at chocolate purchase. Potravinárstvo, 8 (1): 61-66 
http://dx.doi.org/10.5219/325.

11. Lari, A.; Asllani, A., 2013: Quality cost management support system: an effective tool for organisational performance improvement. Total Quality Management and Business Excellence, 20 (3-4): 432-451 http://dx.doi.org/10.1080/14783363.2012.733258.

12. Lin, M. J. J.; Huang, Ch. H.; Chiang, I. Ch., 2012: Explaining trade-offs in new product development speed, cost, and quality: The case of high-tech industry in Taiwan. Total Quality Management and Business Excellence, 23 (9-10): 1107-1123 http://dx.doi.org/10.1080/14783363.2011.637784.

13. Nováková, R.; Kusý, O., 2010: Trends of quality management - quality economy. In: Vysokije technologii, issledovanija, promyšlennost': Sbornik trudov 9. meždunarodnoj naučno-praktičeskoj konferencii "Issledovanije, razrabotka i primenenije vysokich technologij v promyšlennosti”. 22-23. 4. 2010, Sankt-Peterburg, Russia. Tom 4. - Sankt-Peterburg: Izdatel'stvo Politechničeskogo universiteta, pp. 6-11.

14. Nováková, R., 2003: Ekonomické náklady a prínosy z certifikačného procesu systémov manažérstva kvality (The economic costs and gains from the certification process in management quality). In: Research papers Faculty of Materials Science and Technology Slovak University of Technology in Trnava. 15: 109-114.

15. Potkany, M., 2011: Outsourcing v podnikoch drevospracujúceho priemyslu na Slovensku. Zvolen: Vydavatel'stvo TU vo Zvolene.

16. Vetráková, M.; Potkány, M.; Hitka, M., 2013: Outsourcing of facility management. E+M Ekonomie a Management, 16 (1): 80-92.
17. Scheer, L., 2007: Biometria. Zvolen: Technical university in Zvolen.

18. Srivastava, S. K., 2008: Towards estimating Cost of Quality in supply chains. Total Quality Management and Business Excellence, 19 (3): 193-208 http://dx.doi.org/10.1080/14783360701600605.

19. Stasiak-Betlejewska, R., 2012: Value engineering as the way of quality problems solving in the steel construction management, Manufacturing Technology, 12 (13): 242247.

20. Su, Q.; Shi, J. H.; Lai, S. J., 2009: Research on the tradeoff relationship within quality costs: A case study. Total Quality Management and Business Excellence, 20 (12): 1395-1405 http://dx.doi.org/10.1080/14783360903248922.

21. Wu, L., 2010: Managing design quality and conformance quality: models and insights. Total Quality Management and Business Excellence, 21 (4): 383-389 http://dx.doi.org/10.1080/14783361003606597.

\section{Corresponding address:}

Professor DENIS JELAČIĆ, Ph.D.

University of Zagreb

Faculty of Forestry

Svetošimunska 25

HR-10000 Zagreb, CROATIA

e-mail: djelacic@sumfak.hr 